\title{
Kaji Eksperimental Peredam Dinamik dan Energy Harvesting pada Sistem Pegas Massa dengan DVA Tipe Dual Strip
}

\author{
Dewa Anom Pasmadi ${ }^{1}$, Asnawi Lubis ${ }^{2, *}$, Novri Tanti ${ }^{2}$, dan Zulhendri Hasymi ${ }^{2}$ \\ ${ }^{1}$ Program Studi Teknik Mesin, Fakultas Teknik Universitas Lampung \\ ${ }^{2}$ Jurusan Teknik Mesin, Fakultas Teknik Universitas Lampung \\ Jl. Prof. Dr. Sumantri Brojonegoro No.1, Kota Bandar Lampung, 35145 \\ Telp: (0721) 701609 Fax: (0721) 702767 \\ E-mail: asnawi.lubis@eng.unila.ac.id
}

\begin{abstract}
A vibrating system can be suppressed using a vibration damper. One type of vibration dampers is the dynamic vibration absorber (DVA) which usually consists of a mass spring system. In this study DVA of dual strip type is used, which are two strips connected by a spring which are attached by a pin to the main structure. The main structure being tested consists of a mass that has wheels with springs on the left and right. The vibrations that occur in dual-strip DVA is used for energy harvesting using a bimorph piezoelectric type that is attached to a dual-strip DVA. In this study the effectiveness of dual strip DVA in reducing the amplitude of the main structure is observed by varying the spring position connecting the dual strip DVA, and determining the output voltage that can be generated by piezoelectricity. From this study it was found that the effectiveness of dynamic dampers and energy harvesting were obtained for the spring position at the end of the dual strip DVA $(a=L)$. The amplitude of the main structure can be reduced by $29.87 \%$ while the output voltage generated by piezoelectric is 3.59 volts.
\end{abstract}

Key words: Dynamic vibration absorber (DVA), piezoelectric, energy harvesting.

\begin{abstract}
Abstrak
Suatu sistem yang bergetar dapat diredam dengan menggunakan peredam getaran. Salah satu jenis peredam getaran adalah peredam dinamik (dynamic vibration absorber, DVA) yang biasanya terdiri dari sistem pegas massa. Pada penelitian ini digunakan DVA tipe dual strip, yaitu dua buah strip yang dihubungkan dengan pegas yang dipasangkan dengan tumpuan jepit ke struktur utama. Struktur utama yang diuji terdiri dari sebuah massa yang memiliki roda dengan pegas disisi kiri dan kanannya. Getaran yang terjadi pada DVA dual strip dimanfaatkan untuk pemanenan energi (energy harvesting) dengan menggunakan piezoelektrik jenis bimorph yang ditempelkan pada DVA dual strip. Pada penelitian ini dilihat efektivitas dari DVA dual strip terhadap penurunan amplitudo struktur utama dengan memvariasikan posisi pegas yang menghubungkan DVA dual strip serta mencari tegangan listrik keluaran yang dapat dihasilkan oleh piezoelektrik. Dari penelitian yang dilakukan efektivitas peredam dinamik dan energy harvesting didapatkan pada variasi posisi pegas diujung dari DVA dual strip $(a=L)$ dimana panjang strip $(L)$ yaitu 0,3 $\mathrm{m}$, dimana amplitudo struktur utama dapat diredam sebesar 29,87\% dan tegangan listrik keluaran yang dihasilkan piezoelektrik sebesar 3,59 volt.
\end{abstract}

Kata kunci: Peredam dinamik (DVA), piezoelektrik, pemanenan energi.

\section{PENDAHULUAN}

Getaran merupakan gerakan osilasi suatu benda yang mempunyai massa dan kekakuan terhadap posisi keseimbangannya. Benda tersebut akan menghasilkan getaran apabila diberikan gaya gangguan awal [1]. Apabila gaya eksitasi yang diberikan sama dengan atau mendekati frekuensi pribadi dari suatu mesin atau sistem getaran struktur maka getaran yang dihasilkan akan sangat besar. Peristiwa ini dikenal dengan fenomena resonansi. Getaran terdiri dari berbagai jenis yaitu getaran paksa dan getaran bebas serta getaran teredam dan tak teredam [2]. Untuk meredam getaran yang terjadi serta dampak buruk yang diakibatkan oleh getaran dapat dilakukan dengan menambahkan peredam getaran, salah satunya adalah peredam dinamik atau dynamic vibration absorber (DVA). Sistem peredam dinamik atau dynamic vibration absorber (DVA) ditemukan oleh Frahm [3]. Peredam dinamik merupakan sistem peredam yang ditambahkan pada struktur utama. Sistem peredam dinamik ini terdiri atas massa tambahan yang dihubungkan dengan pegas yang dipasangkan pada struktur utama suatu sistem getaran [4].

Getaran yang terjadi pada sistem peredam dinamik dapat dimanfaatkan sebagai penghasil sumber energi listrik dengan teknik pemanenan energi (energy harvesting) yang dapat dilakukan dengan menggunakan piezoelektrik. Piezoelektrik 
merupakan alat pemanenan energi yang dapat dipasangkan atau ditempelkan pada batang kantilever atau suatu sistem getaran struktur [5]. Prinsip kerja dari piezoelektrik adalah dengan mengubah energi mekanik yang berasal dari getaran menjadi energi listrik. Pada piezoelektrik terdapat bagian material yang bermuatan positif dan negatif yang membentuk elektroda sehingga menyebabkan terakumulasinya muatan listrik pada material tersebut [6]. Energi yang dipanen tersebut dapat dimanfaatkan untuk menghasilkan energi listrik daya rendah yang bisa digunakan untuk perangkat elektronik yang berdaya rendah seperti sensor nirkabel. Material piezoelektrik umumnya dibagi menjadi 3 jenis yaitu Kristal, Keramik, Polimer [7].

\section{METODOLOGI PENELITIAN}

Penelitian ini dilakukan di Laboratorium Mekanika Struktur Jurusan Teknik Mesin Universitas Lampung. Penelitian dimulai dengan melakukan studi literatur tentang sistem getaran dan peredam dinamik serta melakukan pemodelan untuk sistem getaran yang diuji. Penelitian dilanjutkan dengan melakukan pembuatan alat serta kaji analitik untuk menurunkan persamaan gerak dari sistem getaran yang diuji.

Sistem getaran yang diuji terdiri dari sebuah massa yang diberi roda dan dua buah pegas di kiri dan di kanan seperti ditunjukkan pada Gambar 1. Pada massa tersebut diberikan gaya gangguan awal (eksitasi) dalam arah horizontal. Kemudian di atas massa tersebut dipasang dual strip yang dihubungkan dengan sebuah pegas yang berfungsi sebagai peredam dinamik atau dynamic vibration absorber (DVA). Pada dual strip ditempel piezoelektrik yang berfungsi untuk pemanenan energi (energy harvesting) dari getaran yang dialami peredam dinamik menjadi energi listrik.

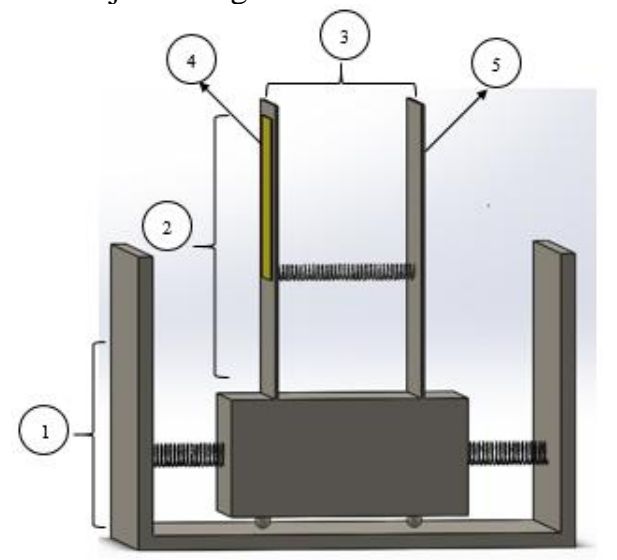

Gambar 1. Pemodelan sistem pegas massa dengan DVA

Keterangan:

1 : Struktur utama (sistem pegas massa)
2 : Peredam dinamik atau dynamic vibration absorber (DVA)

3: Dual strip yang dihubungkan dengan pegas

4 \& 5 : Piezoelektrik bimorph

Setelah selesai dibuat sistem pegas massa dengan DVA dual strip sesuai dengan pemodelan, kemudian dilakukan pengujian dengan menggunakan perangkat universal vibration system (UVS) Gunt Germany. Pengujian ini dilakukan dengan memvariasikan posisi pegas dan posisi piezoelektrik yang terdapat pada dual strip sebanyak 3 kali. Selanjutnya dicari kondisi optimum dari peredam serta tegangan listrik keluaran yang dihasilkan piezoelektrik. Set up alat pengujian yang telah dibuat sesuai dengan pemodelan dapat dilihat pada Gambar 2 .

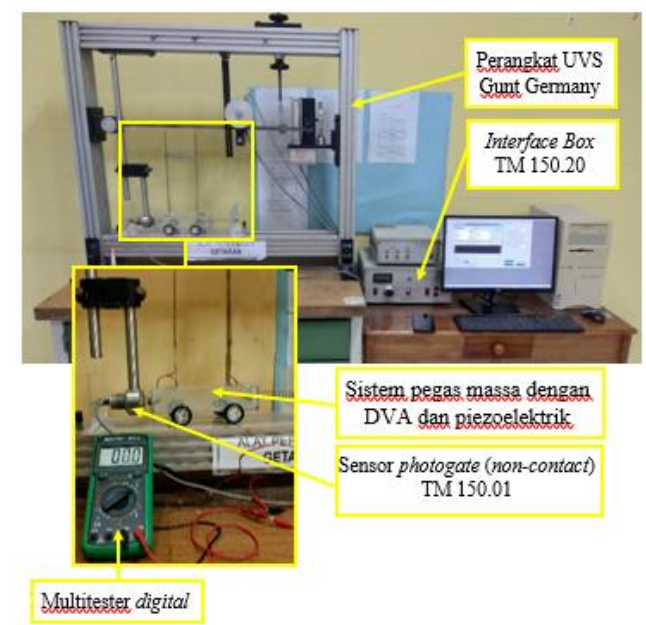

Gambar 2. Set up peralatan pengujian sistem DVA

HASIL DAN PEMBAHASAN

\section{A. Struktur Utama Sistem Pegas Massa}

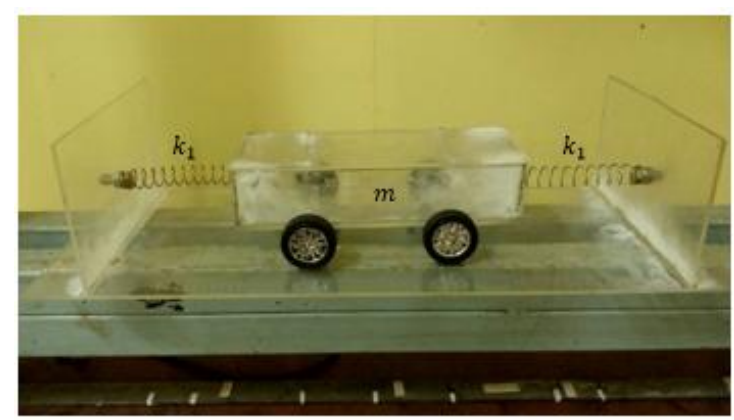

Gambar 3. Struktur utama

Struktur utama sistem pegas-massa yang diuji ditunjukkan pada Gambar 3. memiliki massa $0,24553 \mathrm{~kg}$ dan kekakuan dari pegas $k_{1}$ struktur utama yaitu $657,706 \mathrm{~N} / \mathrm{m}$ dengan gaya eksitasi dalam arah horizontal sebesar 6,5 N. Kemudian diturunkan persamaan gerak untuk mencari frekuensi 
pribadi dari struktur utama tersebut dengan menggunakan diagram benda bebas seperti pada Gambar 4

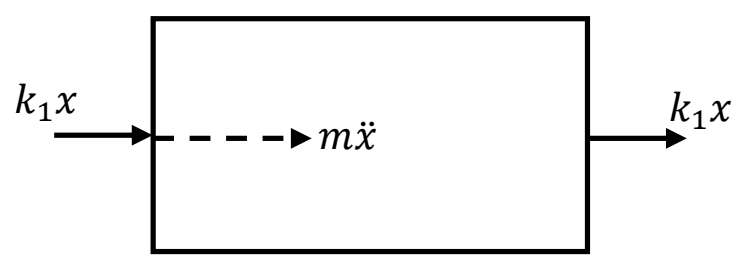

Gambar 4. DBB struktur utama

Persamaan gerak pertama untuk struktur utama didapatkan dari persamaan keseimbangan gaya berikut ini:

$$
\begin{gathered}
\sum F_{x}=m \ddot{x} \\
-k_{1} x-k_{1} x=m \ddot{x} \\
m \ddot{x}+2 k_{1} x=0
\end{gathered}
$$

Dari persamaan (1) diperoleh frekuensi pribadi struktur utama sebelum dipasang peredam dinamik:

$\omega_{n}=\sqrt{\frac{2 k_{1}}{m}}$

$\omega_{n}=\sqrt{\frac{2 \times(328,853 \mathrm{~N} / \mathrm{m})}{0,24553 \mathrm{~kg}}}$

$\omega_{n}=\sqrt{\frac{657,706 \mathrm{~N} / \mathrm{m}}{0,24553 \mathrm{~kg}}}$

$\omega_{n}=51,75 \frac{\mathrm{rad}}{\mathrm{s}}$

$f n=\omega n / 2 \pi=8,23 \mathrm{~Hz}$

Kemudian dari pengujian yang dilakukan dengan menggunakan perangkat universal vibration system (UVS) didapatkan diagram respon dinamik amplitudo terhadap frekuensi dari struktur utama sebelum dipasang peredam dinamik seperti dapat dilihat pada Gambar 5.

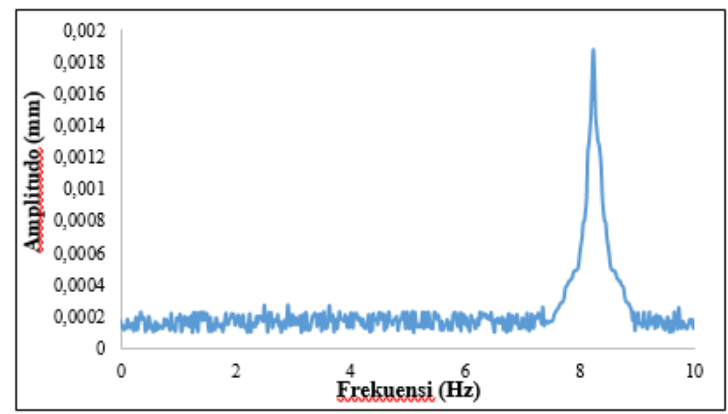

Gambar 5. Amplitudo struktur utama tanpa DVA

Dari Gambar 5 dapat dilihat amplitudo struktur utama sebelum dipasang peredam dinamik DVA dual strip mendekati frekuensi pribadi struktur utama atau mengalami resonansi. Oleh sebab itu maka dipasang peredam dinamik tipe dual strip untuk meredam getaran yang terjadi sehingga dapat mengurangi atau meredam amplitudo struktur utama.

\section{B. Peredam Dinamik Tipe Dual Strip}

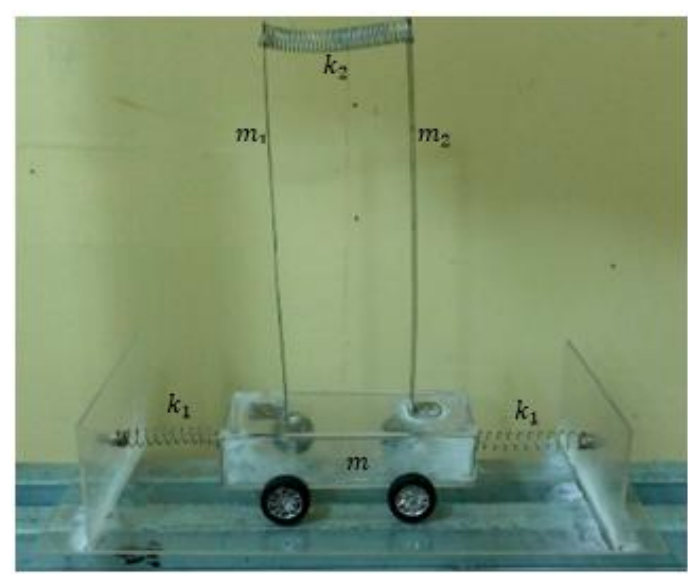

Gambar 6. Sistem peredam dinamik tipe dual strip

Dual strip yang digunakan sebagai peredam dinamik terbuat dari bahan stainless steel (AISI 304) memiliki massa masing-masing yaitu strip pertama $m_{1}$ yaitu $0,05088 \mathrm{~kg}$ dan massa strip kedua $m_{2}$ yaitu $0,02098 \mathrm{~kg}$ dan memiliki modulus elastisitas $193000000 \mathrm{~N} / \mathrm{m}^{2}$. Sedangkan pegas yang menghubungkan dual strip tersebut memiliki kekakuan $k_{2}$ yaitu $20 \mathrm{~N} / \mathrm{m}$.

Tabel 1. Data dimensi DVA dual strip

\begin{tabular}{|c|c|c|}
\hline & Strip 1 & Strip 2 \\
\hline $\begin{array}{c}\text { Tebal } \\
(\mathrm{t})\end{array}$ & $1,5 \mathrm{~mm}(0,0015 \mathrm{~m})$ & $1 \mathrm{~mm}(0,001 \mathrm{~m})$ \\
\hline $\begin{array}{c}\text { Lebar } \\
(\mathrm{b})\end{array}$ & $31 \mathrm{~mm}(0,031 \mathrm{~m})$ & $26 \mathrm{~mm}(0,026 \mathrm{~m})$ \\
\hline $\begin{array}{c}\text { Panjang } \\
(\mathrm{L})\end{array}$ & $300 \mathrm{~mm}(0,3 \mathrm{~m})$ & $300 \mathrm{~mm}(0,3 \mathrm{~m})$ \\
\hline
\end{tabular}

Menghitung kekakuan bending dual strip:

$$
\begin{aligned}
D & =\frac{E t^{3}}{12\left(1-v^{2}\right)} \\
D_{1} & =\frac{193000000 \times 0,0015^{3}}{12\left(1-0,3^{2}\right)} \\
& =0,0596 \mathrm{~N} \cdot \mathrm{m} \\
D_{2} & =\frac{193000000 \times 0,001^{3}}{12\left(1-0,3^{2}\right)} \\
& =0,0176 \mathrm{~N} \cdot \mathrm{m}
\end{aligned}
$$

Kemudian dihitung kekakuan strip 1 dan strip 2:

$$
\begin{aligned}
K_{3} & =\frac{D_{1} \times b_{1}}{a^{3}} \\
& =\frac{0,0596 \times 0,031}{0,3^{3}} \\
& =0,0684 \mathrm{~N} / \mathrm{m} \\
K_{4} & =\frac{D_{2} \times b_{2}}{a^{3}} \\
& =\frac{0,0176 \times 0,026}{0,3^{3}} \\
& =0,0169 \mathrm{~N} / \mathrm{m}
\end{aligned}
$$

Kemudian didapatkan $K_{\text {tot }}$ dari DVA dual strip yaitu:

$K_{\text {tot }}=\frac{1}{K_{2}}+\frac{1}{K_{3}}+\frac{1}{K_{4}}$ 


$$
\begin{aligned}
& =\frac{1}{20}+\frac{1}{0,0684}+\frac{1}{0,0169} \\
& =73,841 \mathrm{~N} / \mathrm{m}
\end{aligned}
$$

Kemudian diturunkan persamaan gerak dari sistem peredam dinamik dual strip dengan menggunakan diagram benda bebas (DBB) terpisah seperti pada Gambar 7.

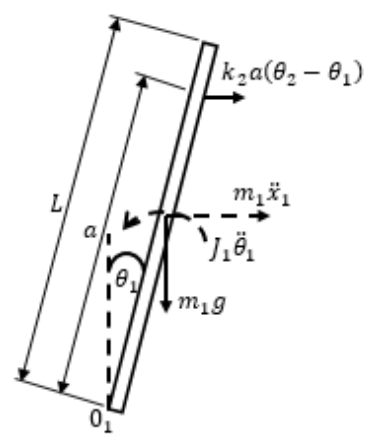

(a)

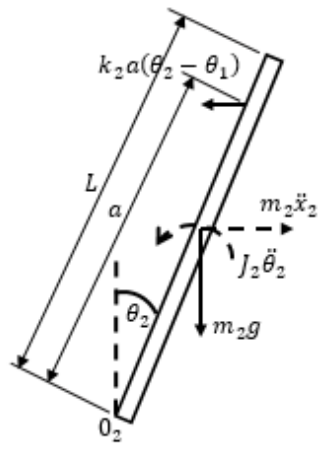

(b)
Gambar 7. (a) DBB strip pertama (b) DBB strip kedua

Penurunan persamaan gerak kedua untuk strip pertama yaitu sebagai berikut:

$\sum M o_{1}=J \ddot{\theta}$

$J_{1} \ddot{\theta}_{1}-m_{1} \ddot{x}_{1} \frac{L}{2}-m_{1} g \frac{L}{2} \theta_{1}-k_{2} a\left(\theta_{2}-\theta_{1}\right) a=0$

$\frac{m_{1} L^{2}}{12} \ddot{\theta}_{1}-m_{1}\left(\ddot{x}-\frac{L}{2} \ddot{\theta}_{1}\right) \frac{L}{2}-m_{1} g \frac{L}{2} \theta_{1}-$

$k_{2} a^{2}\left(\theta_{2}-\theta_{1}\right)=0$

$\frac{m_{1} L^{2}}{12} \ddot{\theta}_{1}+\frac{m_{1} L^{2}}{4} \ddot{\theta}_{1}-\frac{m_{1} L}{2} \ddot{x}-m_{1} g \frac{L}{2} \theta_{1}-k_{2} a^{2} \theta_{2}+$ $k_{2} a^{2} \theta_{1}=0$

$\left(\frac{m_{1} L^{2}}{12}+\frac{m_{1} L^{2}}{4}\right) \ddot{\theta}_{1}-\frac{m_{1} L}{2} \ddot{x}-\left(m_{1} g \frac{L}{2}+k_{2} a^{2}\right) \theta_{1}-$ $k_{2} a^{2} \theta_{2}=0$

$\frac{m_{1} L^{2}}{3} \ddot{\theta}_{1}-\frac{m_{1} L}{2} \ddot{x}-\left(m_{1} g \frac{L}{2}+k_{2} a^{2}\right) \theta_{1}-k_{2} a^{2} \theta_{2}=0$

Penurunan persamaan gerak ketiga untuk strip kedua yaitu sebagai berikut:

$\sum M o_{2}=J \ddot{\theta}$

$J_{2} \ddot{\theta}_{2}-m_{2} \ddot{x}_{2} \frac{L}{2}-m_{2} g \frac{L}{2} \theta_{2}+k_{2} a\left(\theta_{2}-\theta_{1}\right) a=0$

$\frac{m_{2} L^{2}}{12} \ddot{\theta}_{2}-m_{2}\left(\ddot{x}-\frac{L}{2} \ddot{\theta}_{2}\right) \frac{L}{2}-m_{2} g \frac{L}{2} \theta_{2}+$

$k_{2} a^{2}\left(\theta_{2}-\theta_{1}\right)=0$

$\frac{m_{2} L^{2}}{12} \ddot{\theta}_{2}+\frac{m_{2} L^{2}}{4} \ddot{\theta}_{2}-\frac{m_{2} L}{2} \ddot{x}-m_{2} g \frac{L}{2} \theta_{2}+k_{2} a^{2} \theta_{2}-$ $k_{2} a^{2} \theta_{1}=0$

$\left(\frac{m_{2} L^{2}}{12}+\frac{m_{2} L^{2}}{4}\right) \ddot{\theta}_{2}-\frac{m_{2} L}{2} \ddot{x}-\left(m_{2} g \frac{L}{2}+k_{2} a^{2}\right) \theta_{2}-$ $k_{2} a^{2} \theta_{1}=0$

$\frac{m_{2} L^{2}}{3} \ddot{\theta}_{2}-\frac{m_{2} L}{2} \ddot{x}-\left(m_{2} g \frac{L}{2}+k_{2} a^{2}\right) \theta_{2}-k_{2} a^{2} \theta_{1}=0$

Penurunan persamaan gerak untuk peredam dinamik dilakukan dengan posisi pegas yang berada pada ketinggian $a=L$, dimana $L$ merupakan panjang dual strip yaitu $0,3 \mathrm{~m}$. Kemudian tiga persamaan gerak yaitu persamaan struktur utama dan peredam dinamik disusun dalam bentuk matriks massa dan matriks kekauan sehingga didapatkan:

$$
\begin{aligned}
& {\left[\begin{array}{ccc}
m & 0 & 0 \\
-\frac{m_{1} L}{2} & \frac{m_{1} L^{2}}{3} & 0 \\
-\frac{m_{2} L}{2} & 0 & \frac{m_{2} L^{2}}{3}
\end{array}\right]\left\{\begin{array}{c}
\ddot{x} \\
\ddot{\theta}_{1} \\
\ddot{\theta}_{2}
\end{array}\right\}+} \\
& {\left[\begin{array}{ccc}
2 k_{1} & 0 & 0 \\
0 & -\frac{m_{1} g L}{2}+k_{2} a^{2} & -k_{2} a^{2} \\
0 & -k_{2} a^{2} & -\frac{m_{2} g L}{2}+k_{2} a^{2}
\end{array}\right]\left\{\begin{array}{l}
x \\
\theta_{1} \\
\theta_{2}
\end{array}\right\}=0}
\end{aligned}
$$

Misal:

$$
\begin{array}{ll}
x=A \operatorname{Sin} \omega t & \ddot{x}=-\omega^{2} A \operatorname{Sin} \omega t \\
\theta_{1}=A_{1} \operatorname{Sin} \omega t & \ddot{\theta}_{1}=-\omega^{2} A_{1} \operatorname{Sin} \omega t \\
\theta_{2}=A_{2} \operatorname{Sin} \omega t & \ddot{\theta}_{2}=-\omega^{2} A_{2} \operatorname{Sin} \omega t
\end{array}
$$

$\left[\begin{array}{ccc}m & 0 & 0 \\ -\frac{m_{1} L}{2} & \frac{m_{1} L^{2}}{3} & 0 \\ -\frac{m_{2} L}{2} & 0 & \frac{m_{2} L^{2}}{3}\end{array}\right]\left\{\begin{array}{l}-\omega^{2} A \operatorname{Sin} \omega t \\ -\omega^{2} A_{1} \operatorname{Sin} \omega t \\ -\omega^{2} A_{2} \operatorname{Sin} \omega t\end{array}\right\}+$

$\left[\begin{array}{ccc}2 k_{1} & 0 & 0 \\ 0 & -\frac{m_{1} g L}{2}+k_{2} a^{2} & -k_{2} a^{2} \\ 0 & -k_{2} a^{2} & -\frac{m_{2} g L}{2}+k_{2} a^{2}\end{array}\right]\left\{\begin{array}{c}A \operatorname{Sin} \omega t \\ A_{1} \operatorname{Sin} \omega t \\ A_{2} \operatorname{Sin} \omega t\end{array}\right\}=0$

Kemudian pada persamaan terakhir disubtitusikan nilai-nilai yang diketahui. Dengan membuat determinan dari matrik koefisien peramaan di atas sama dengan nol, didapatkan:

$=$

$-2,35822824132 \times 10^{-7} \omega^{6}+$ $0,0015611532384 \omega^{4}-1,50965228461033 \omega^{2}-$ 123,6657879005

Kemudian diperoleh frekuensi pribadi struktur utama dan frekuensi DVA dual strip berturut-turut yaitu sebagai berikut:

$\omega_{1}=8,712 \mathrm{rad} / \mathrm{s}$

$\omega_{2}=35,707 \mathrm{rad} / \mathrm{s}$

$\omega_{3}=73,627 \mathrm{rad} / \mathrm{s}$

\section{Pengaruh Variasi Posisi Pegas DVA Dual Strip}

Untuk melihat efektivitas dari peredam dinamik DVA dual strip dilakukan variasi posisi dari pegas yang menghubungkan DVA dual strip tersebut. Penelitian dilakukan dengan memvariasikan posisi pegas (a) terhadap panjang strip $(L)$ sebanyak 3 kali yaitu pada $a=\frac{1}{2} L, a=\frac{3}{4} L$ dan $a=L$, dimana panjang dual strip $(L)$ yaitu $0,3 \mathrm{~m}$. Kemudian dilihat pengaruh dari peredam dinamik DVA terhadap amplitudo struktur utama sebelum dipasang peredam dinamik. Gambar 8 merupakan grafik ampiltudo terhadap frekuensi untuk posisi pegas $a=\frac{1}{2} \mathrm{~L}$. 


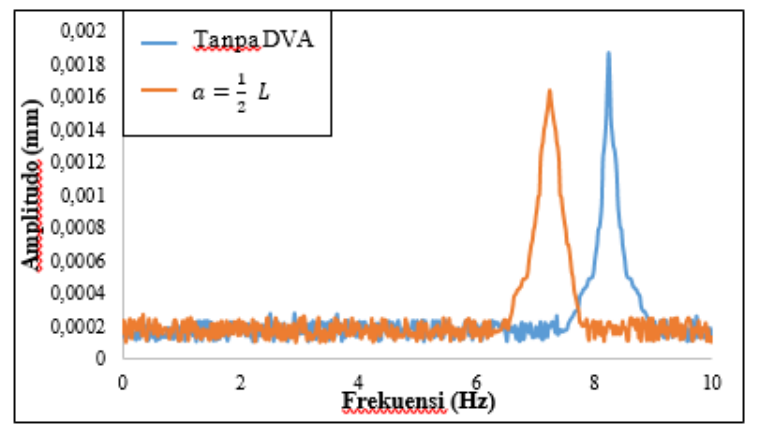

Gambar 8. Pengaruh pegas pada ketinggian $a=\frac{1}{2} L$

Gambar 8. menunjukkan grafik amplitudo terhadap frekuensi struktur utama sebelum dan setelah dipasang peredam dinamik saat diberikan gaya gangguan horizontal sebesar 6,5 N. Grafik puncak amplitudo terhadap frekuensi dari struktur utama sebelum dipasang peredam dinamik yaitu $0,00187 \mathrm{~mm}$ dan setelah dipasang peredam dinamik mengalami penurunan menjadi $0,00164 \mathrm{~mm}$. Sehingga didapatkan pengaruh peredam dinamik dengan posisi pegas di tengah dual strip atau pada ketinggian $a=\frac{1}{2} L$ adalah dapat meredam amplitudo sebesar $12,29 \%$.

Pada ketinggian posisi pegas $a=\frac{3}{4} L$ saat struktur utama diberikan gaya gangguan horizontal yang sama yaitu sebesar 6,5 $\mathrm{N}$ amplitudo struktur utama mengalami penurunan yang lebih besar. Dimana puncak amplitudo terhadap frekuensi sebelum dan setelah dipasang DVA mengalami penurunan dari $0,00187 \mathrm{~mm}$ menjadi $0,00154 \mathrm{~mm}$ atau dapat diredam sebesar 17,64 \%. Grafik amplitudo terhadap frekuensi struktur utama sebelum dan setelah dipasang peredam dinamik dapat dilihat pada Gambar 9.

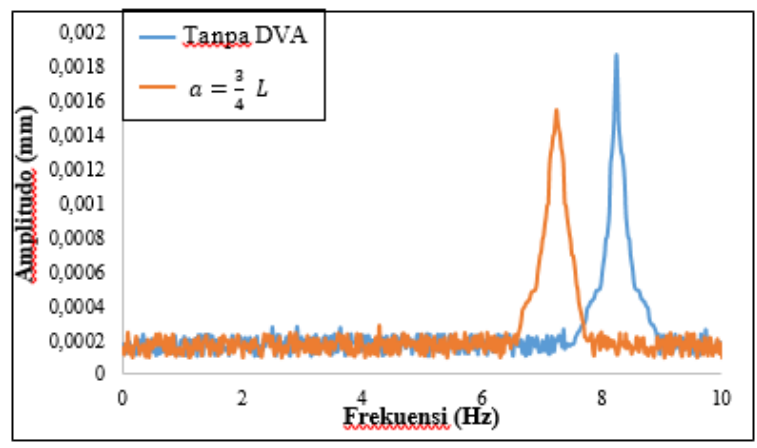

Gambar 9. Pengaruh pegas pada ketinggian $a=\frac{3}{4} L$

Posisi pegas DVA dual strip dengan ketinggian pegas pada ujung dual strip atau pada ketinggian $a=$ $L$ memiliki pengaruh yang paling signifikan dibandingkan dengan variasi 2 posisi pegas sebelumnya. Dengan diberikan arah dan besar gaya gangguan yang sama puncak amplitudo terhadap frekuensi sebelum dan setelah dipasang DVA mengalami penurunan dari $0,00187 \mathrm{~mm}$ menjadi $0,00131 \mathrm{~mm}$ atau dapat diredam sebesar 29,94\%. Gambar 10. menunjukkan grafik amplitudo terhadap frekuensi struktur utama sebelum dan setelah dipasang peredam dinamik.

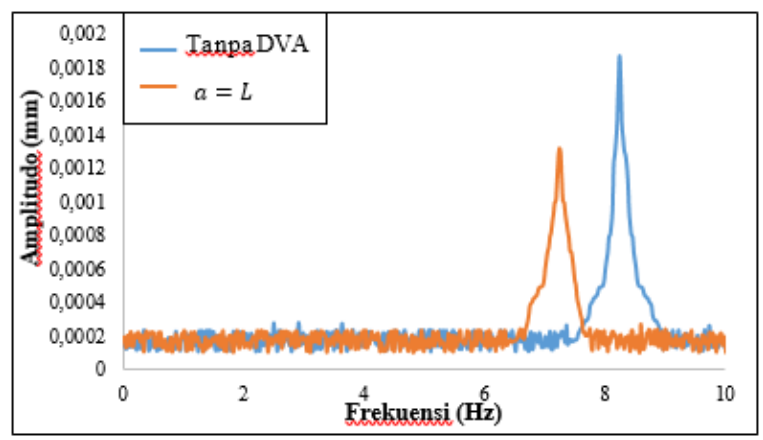

Gambar 10. Pengaruh pegas pada ketinggian $a=L$

\section{Energy Harvesting}

Pengujian energy harvesting menggunakan piezoelektrik yang dipasangkan pada DVA dual strip yaitu pada strip pertama dan strip kedua dengan rangkaian parallel. Piezoelektrik yang digunakan adalah jenis bimorhp, terbuat dari bahan keramik yaitu lead zirconate titanate (PZT) yang memiliki panjang $80 \mathrm{~mm}$, lebar $33 \mathrm{~mm}$ dan tebal 0,6 mm. Sedangkan DVA dual strip yang digunakan memiliki panjang (L) yaitu $0,3 \mathrm{~m}$ dan memiliki kekakuan total dari dual strip dan pegas yang menghubungkannya yaitu $73,841 \mathrm{~N} / \mathrm{m}$. Hasil dari pengujian terhadap tegangan listrik keluaran piezoelektrik ditunjukkan pada Tabel 2 .

Tabel 2. Tegangan listrik keluaran piezoelektrik terhadap posisi pegas dual strip

\begin{tabular}{|c|c|c|c|}
\hline \multirow{2}{*}{ No. } & $\begin{array}{c}\text { Posisi } \\
\text { pegas (m) }\end{array}$ & $\begin{array}{c}\text { Posisi } \\
\text { piezoelektrik }\end{array}$ & $\begin{array}{c}\text { Tegangan } \\
\text { listrik keluaran } \\
\text { (Volt) }\end{array}$ \\
\hline \multirow{3}{*}{ 1. } & \multirow{2}{*}{$a=\frac{1}{2} L$} & Bawah & 1,42 \\
\cline { 3 - 4 } & \multirow{2}{*}{2.} & Tengah & 0,53 \\
\cline { 3 - 4 } & \multirow{2}{*}{$a=\frac{3}{4} L$} & Atas & 0,2 \\
\hline \multirow{2}{*}{3.} & \multirow{3}{*}{$a=L$} & Bawah & 1,91 \\
\cline { 3 - 4 } & & Tengah & 0,93 \\
\cline { 3 - 4 } & & Atas & 0,32 \\
\cline { 3 - 4 } & & Tengah & 3,59 \\
\cline { 3 - 4 } & & Atas & 1,10 \\
\hline
\end{tabular}

Tabel 2. menunjukkan tegangan listrik keluaran terbesar yang dihasilkan piezoelektrik berdasarkan variasi posisi piezoelektrik dan variasi posisi pegas pada DVA dual strip. Hasil tersebut dapat dilihat lebih jelas pada Gambar 11 


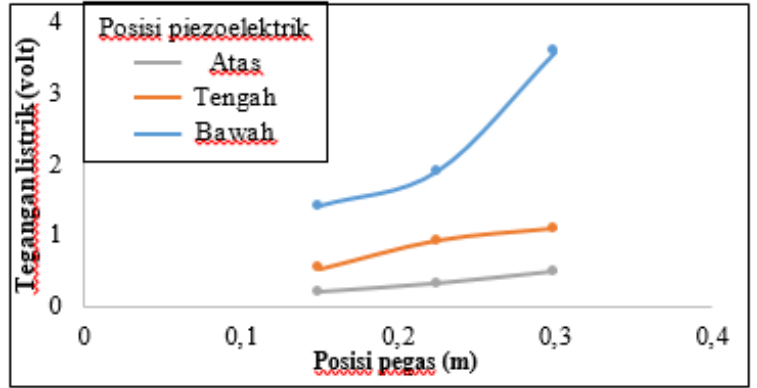

Gambar 11. Grafik posisi pegas terhadap tegangan listrik keluaran dari piezoelektrik

Dapat dilihat bahwa tegangan listrik keluaran terbesar dihasilkan pada ketinggian pegas $a=L$ atau diujung dari DVA dual strip dengan posisi piezoelektrik pada bagian bawah dari DVA dual strip. Hal tersebut berbanding lurus dengan amplitudo terbesar yang terjadi pada DVA dual strip, dimana pada posisi pegas $a=L$ merupakan posisi peredam dinamik yang mengalami amplitudo paling besar karena kekakuan dual strip semakin berkurang. Sedangkan piezoelektrik yang diletakkan pada bagian bawah DVA dual strip juga mengalami defleksi sehingga menghasilkan tegangan listrik keluaran yang lebih besar.

\section{KESIMPULAN}

Adapun kesimpulan yang dapat ditarik dari hasil penelitian tugas akhir ini adalah sebagai berikut:

1. Efektivitas peredam dinamik DVA dual strip pada kondisi optimum didapatkan dengan menggunakan ketinggian posisi pegas pada $a=L$ dimana amplitudo terhadap frekuensi pada struktur utama dapat diturunkan atau diredam sebesar 29,94\%.

2. Tegangan listrik keluaran piezoelektrik yang dipasangkan pada DVA dual strip untuk kondisi optimum didapatkan pada ketinggian posisi pegas $a=L$ atau pada ujung dual strip dimana panjang strip ( $L$ ) yaitu 0,3 $\mathrm{m}$ dan posisi piezoelektrik pada bagian bawah DVA dual strip.

\section{DAFTAR PUSTAKA}

[1] Thomson, W. T., 1993, "Theory of Vibration With Applications". 4th Edition. Prentice Hall, Inc. New Jersey.

[2] Rao, S. S., 2004, "Mechanical Vibration". 5th Edition. Prentice-Hall. New Jersey.

[3] Frahm, H., 1911, "Device for Damping Vibrations of Bodies". US Patent No. 989958.
[4] Dimaragonas, A.D., dan Haddad, S., 1992, "Vibration for Engineers". Prentice-Hall, Inc., Englewood Cliffs, New Jersey.

[5] Hidayatullah, W., Syukri, M., dan Syukriyadin, 2016, "Perancangan Prototype Penghasil Energi Listrik Berbahan Dasar Piezoelektrik". Unsyiah, Aceh.

[6] Hill, D., dan Tong, N., 2013, "Assessment of Piezoelectric Materials for Roadway Energy Harvesting". DNV KEMA, California Energy Commission, California.

[7] Ebrahimi, F., 2013, "Piezoelectric Materials and Devices-Practice And Applications". Rijeka., Croatia. 